\title{
MEMBANGUN KESADARAN HUKUM MASYARAKAT DI MASA PANDEMI COVID-19 MELALUI PERAN KELUARGA
}

\author{
Rahma Aulia \\ Institut Agama Islam Negeri Kudus \\ Email : rahmaaulia@iainkudus.ac.id
}

\begin{abstract}
This study aims to determine the factors that encourage people to ignore regulations related to Covid-19 and the function of the family in building public legal awareness. The type of research used is empirical juridical with a qualitative approach. The data sources used include primary data and secondary data. The results of the study show that the existence of regulations that regulate the prevention of the spread of Covid-19 in Indonesia is currently by some people still neglecting its implementation, this is influenced by several factors including conspiratorial theories and economic conditions. One of the efforts to raise public legal awareness to comply with these regulations is through optimizing the function of socialization and family education from parents. The role of parents who remind each other to care about maintaining health and obeying the rule of law will have the greatest impact on their own legal awareness, because parents are children's personal role models. So maximizing legal awareness is maximizing the role of parents and families.
\end{abstract}

Keywords: Family, Covid-19, Legal Awareness

\begin{abstract}
Abstrak
Penelitian ini bertujuan untuk mengetahui faktor pendorong masyarakat abai terhadap regulasi terkait covid-19 dan fungsi keluarga dalam membangun kesadaran hukum masyarakat. Jenis penelitian yang digunakan adalah yuridis empiris dengan pendekatan kualitatif. Adapun sumber data yang digunakan diantaranya data primer dan data sekunder. Hasil penelitian menunjukkan bahwa keberadaan regulasi yang mengatur terkait pencegahan meluasnya covid19 di Indonesia saat ini oleh sebagian masyarakat masih abai dalam implementasinya, hal tersebut dipengaruhi beberapa faktor diantaranya teori konspiratif dan kondisi ekonomi. Salah satu upaya menumbuhkan kesadaran hukum masyarakat untuk mentaati regulasi tersebut adalah melalui optimalisasi fungsi sosialisasi dan edukasi keluarga dari orang tua. Peran orang tua yang saling mengingatkan anaknya untuk peduli terhadap menjaga kesehatan dan mematuhi aturan hukum akan berdampak paling besar pada kesadaran hukumnya sendiri, karena orang tua adalah panutan pribadi anak. Sehingga memaksimalkan kesadaran hukum adalah memaksimalkan peran orang tua dan keluarga.
\end{abstract}

Kata Kunci: Keluarga, Covid-19, Kesadaran Hukum 


\section{PENDAHULUAN}

Meningkatnya kasus Covid-19 di Indonesia salah satunya disebabkan oleh minimnya kesadaran hukum masyarakat akan protokol kesehatan. Melalui siaran berita, iklan televisi, papan reklame, instruksi kepala daerah, dan lain sebagainya sudah digalakkan pemerintah untuk terus menggaungkan gerakan $5 \mathrm{M}$ yaitu memakai masker, mencuci tangan, menjaga jarak, menjauhi kerumunan dan membatasi mobilitas serta interaksi. Namun kenyataannya masih ditemukan beberapa masyarakat yang abai, tidak memakai masker dengan alasan lupa, masih ditemukan mereka yang asyik berkerumun dengan alasan menghilangkan kebosanan karena di rumah saja, bahkan yang lebih parahnya ditemukan masyarakat yang positif terinfeksi corona berkeliaran seenaknya dengan alasan mereka tidak merasakan gejala apa-apa. Melihat realita tersebut tentunya sangat berbanding terbalik dengan upaya yang dilakukan oleh pemerintah.

Sampai bulan Juli 2021, ratusan regulasi telah dibuat, dengan mengkatagorikan beberapa jenis, dari pengaturan Anggaran dan Pengadaan Barang dan Jasa, Aparatur Sipil Negara, Imigrasi, Jasa Keuangan, Kesehatan, Ketenagakerjaan, Pasar Modal, Pendidikan, Peradilan, Perdagangan, Perpanjakan dan Bea Cukai, Tata Kelola Lembaga Pemerintah, Transportasi hingga dikeluarkannya Pemberlakukan Pembatasan Kegiatan Masyarakat (PPKM) Darurat,demi menengendalikan tatanan kehidupan di masa Covid-19.

Meskipun lagi-lagi regulasi tersebut dalam penerapannya belum optimal, terlihat dari meledaknya kasus covid-19 di Indonesia yang pada akhirnya Menteri Kemaritiman dan Ivestasi Republik Indonesia Luhut Binsar Panjaitan selaku koordinator PPKM Jawa dan Bali menyampaikan permohonan maaf melalui media, dimana menurut Beliau Pemberlakukan Pembatasan Kegiatan Masyarakat (PPKM) yang diterapkan hampir sebulan di Jawa dan Bali dirasa belum maksimal, masyarakat masih banyak yang mengeluhkan Pemberlakuan PPKM karena mereka berpendapat bahwa PPKM hanya membuat ekonomi semakin sulit, kegiatan jual beli makin dipersempit.

Lonjakan kasus Covid-19 di Indonesia semakin dirasakan pada pertengahan tahun 2021. Data statistik pada laman covid19.go.id, yang menunjukkan lonjakan kasus Covid-19 di Indonesia terus mengalami peningkatan: 


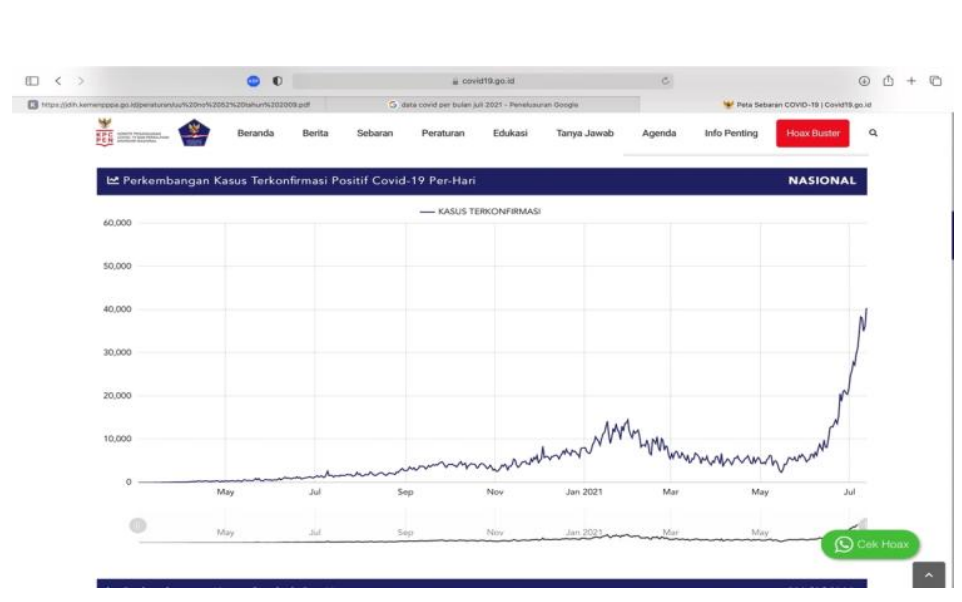

Sumber: https:/ / covid19.go.id/peta-sebaran-covid19

Melihat keadaan Indonesia satu bulan yang lalu, tepatnya pada bulan Juni 2021, kasus virus corona di Indonesia melonjak drastis, data menunjukkan penambahan sebanyak 40.427(sumber dari website Covid19.go.id)yang merupakan kasus aktif, padahal bulan-bulan sebelumnya data kasus corona di Indonesia sempat menunjukkan penurunan dengan angka tidak sampai puluhan ribu perharinya hingga bulan April 2021. Menurut analisis dari Kementerian Kesehatan, peningkatan angka kasus corona di Indonesia disebabkan oleh dilakukannya kunjungan antar keluarga untuk saling silaturahmi ketika lebaran tahun ini, dan ditambah keberadaan mutasi virus baruyang berasal dari India, Afrika dan Inggrisyang mana dianggap penularannya lebih cepat (Sehatnegeriku.Kemkes.go.id)

Merujuk pada penyebab pertama peningkatan kasus covid di Indonesia adalah adanya kunjungan saat lebaran Idul Fitri, masyarakat yang masih mementingkan budaya tanpa melihat bahaya virus yang ada. Padahal Islam mengajarkan umatnya untuk bertafakkur(Indriya, 2020), dengan mengingat pada kisah Umar bin Khattab, dimana pada saat itu wabah melanda di daerah Awamas, kota yang berada di dekat Yerussalem (perbatasan sebelah barat). Dalam kisah tersebut yang dijelaskan dalam karya Muhammad Husein Haekal: terjadinya suatu wabah hingga ke Negeri Syam yang terkadang daerah tersebut disebut sebagai Suriah Palestina, Suriah Raya hingga ke Irak. Dimana peristiwa tersebut terjadi pada akhir 17 Hijriah, yang pada akhirnya menimbulkan kepanikan besar. Mengingat pada hadis yang disampaikan oleh Abdurrahman bin Auf tentang Nabi Muhammad SAW: "Apabila kalian mendengar wabah pada suatu daerah, janganlah kalian memasukinya, dan apabila penyakit itu melanda suatu negeri sedang kalian kalian di dalamnya, maka janganlah kalian berlari dari negeri itu." (Muttafaqun 'alaihi, HR. Bukhari \& Muslim). 
Bulan April Tahun 2021 Satuan Tugas Penanganan Covid 19 telah mengantisipasi lonjakan kasus covid di Indonesia melalui Surat Edaran Nomor 13 Tahun 2021 Tentang Peniadaan Mudik Hari Raya Idul Fitri Tahun 1442 H dan Upaya Pengendalian Penyebaran Corona Virus Disease 2019 selama bulan suci Ramadhan 1442 H.Namun pada realitanya masyarakat tetap lebih memilih pola kebiasaan mereka untuk mengunjungi saudara dan kerabatnya padanuansa idul fitri, yang pada akhirnya mengakibatkan meroketnya angka penularan virus covid-19. Padahal dengan naiknya angka covid di Indonesia, tingkat ksejahteraan masyarakat akandirasa semakin sulit.

Strategi jitu terus dikembangkan oleh Pemerintah, dan diharapkan dimasa penerapan program belajar, bekerja, serta beraktivitas dari rumah, peran keluarga saat ini yang akhirnya diharapkan. Tentu dengan adanya program tersebut, fungsi keluarga dapat dimaksimalkan demi meminimalisir penularan virus covid-19 di Indonesia. Karena dalam hal ini keluarga merupakan kelompok terkecil yang mana bisa membentuk pola pikir anak menjadi baik dengan cara orangtua yang mencontohkan seuatu yang baik kepada anaknya. Dengan orang tua membiasakan sesuatu yang benar kepada anak, maka otomatis akan berdampak pada pemembentukan pola kebiasaan baik itu sendiri kepada diri orangtua tersebut.

Beredarnya berita hoax yang membuat keadaan semakin kisruh yang mana akan membuat pemikiran masyarakat semakin kacau, karena masyarakat masih menerka akan benar atau tidaknya virus covid-19 ini, ditambah dengan simpang siurnya bahaya dari program vaksinasi. Maka dalam hal ini melalui peran Keluarga diharapkan bisa menyaring informasi yang didapatkan oleh masing-masing anggota Keluarga.Antar individu sebaiknya tidak mudah untuk membagikan berita yang belum benar keberadaannya. Terlebih pada jaman yang serba teknologi ini, banyak ditemukan pesan whatsapp yang belum teruji kebenarannya (Rahadi, 2017: 58-70).

Menumbuhkan pentingnya Literasi digital untuk menghentikan penyebaran berita yang tidak benar (hoax) merupakan salah satu sikap yang bisa dikembangkan untuk mengurangi kenaikan angka covid di Indonesia. Apalagi di era modern iniyang semua informasi bisa diakses melalui teknolgi, berdampak mudahnya seseorang dikuasasi oleh berita yang tidak benar adanya (hoax). Indonesia sudah mengeluarkan aturan bagi penyebar berita hoax yang dapat dihukum penjara 2 hingga 10 tahun (dengan melihat kesalahan yang dilakukan oleh indivu tersebut). Aturan tersebut semata mata dibuat agar masyarakat tidak mudah menyimpulkan suatu kejadian yang akhirnya menjadi berita yang tidak benar (Putri et al., 2020: 98). 
Diterapkannya hukum oleh masyarakat di Indonesia merupakan suatu aspek yang penting untuk merealisasikan suatu tujuan. Diantaranya yaitu merealisasikan tujuan negara yakni melindungi segenap bangsa Indonesia dan seluruh tumpah darah Indonesia, memajukan kesejahteraan umum, mencerdaskan kehidupan bangsa, melaksanakan ketertiban dunia yang berdasarkan kemerdekaan, perdamaian abadi dan keadilan sosial. Tidak hanya itu saja kesadaran hukum oleh masyarakat tentu sangat diperlukan demi tercapainya suatu kepastian dan keadilan. Untuk membangun kesadaran hukum di masyarakat, tentu diperlukan penanaman sejak dini, agar tercapai kepatuhan hukum secara maksimal. Oleh sebab itulah peranan keluarga sangat penting dalam hal membangun kesadaran hukum di masyarakat, demi mencapai penurunan kasus corona di Indonesia, sehingga bisa menormalkan perekonomian negara serta mengembalikan tatanan kehidupan kearah yang lebih baik dimasa pandemi.

Penelitian yang mengkaji tentang fungsi keluarga dalam pencegahan corona virus pada dasarnya sudah beberapa kali dilakukan, baik dalam bentuk penelitian normatif maupun empiris. Seperti penelitian yang dilakukan oleh Mughni Labib Ilhamuddin Is Ashidiqie dengan judul Peran Keluarga Dalam Mencegah Corona Virus Disease 2019 (Ashidiqie, 2020). Hasil kajiannya menelusuri pentingnya peran keluarga dalam mencegah persebaran wabah Covid-19. Selain itu, dalam artikel lain yang ditulis oleh dengan judul Peran Keluarga dalam Pencegahan Wabah Covid. (Yuliati, 2021) Hasil kajiannya bertujuan memberikan edukasi dan diskusi pentingnya peran keluarga dalam mencegah persebaran wabah Covid-19. Dalam tulisan tersebut, si penulis berasumsi bahwa keluarga memiliki peran yang sangat penting dalam membantu upaya pemerintah dalam memutus mata rantai persebaran Covid-19.

Seperti yang telah disinggung pada kedua artikel di atas bahwa persamaan antara penelitian sebelumnya dengan penelitian ini adalah sama-sama mengkaji pentingnya fungsi keluarga dalam pencegahan Covid-19, adapun perbedaannya adalah terletak permasalahan yang menjadi objek kajian. Kajian penelitian ini lebih memfokuskan pada faktor yang menyebabkan masyarakat abai akan protokol kesehatan utamanya peraturan yang telah ditetapkan pemerintah demi memutus persebaran Covid-19, serta peran keluarga dalam meningkatkan kesadaran hukum demi terciptanya perlindungan antar sesame warga khususnya di daerah Jawa Tengah.

\section{METODE PENELITIAN}

Penelitian yang digunakan dalam penulisan ini adalah yuridis normatif yang mengkaji peran keluarga dalam mencegah penularan 
Covid-19 dan upaya peningkatan kesadaran hukum khsususnya warga di daerah Kudus dan Semarang. Penelitian ini menggunakan pendekatan sosial legal yang bertujuan menggambarkan suatu kenyataan secara jelas dengan didukung dengan data yang diperoleh melalui analisis penulis dari suatu realita yang terjadi.

Metode analisis data yang dilakukan dengan mengumpulkan data melalui telaah data primer dan dara sekunder. Pengumpulan data primer dilakukan dengan cara mengamati secara langsung pada objek yang diteliti khususnya wawancara pada beberapa sumber di daerah Kudus dan Semarang dengan maksud membandingkan bagaimana cara pandang masyarakat ibukota Provinsi Jawa Tengah dengan Kabupaten Kudus yang mana pernah menduduki puncak tertinggi angka Covid-19 di Indonesia. Wawancara adalah tanya jawab yang dilakukan secara langsung atas beberapa pertanyaan yang dibuat oleh pewawancara yang kemudian dapat dikembangkan pada saat penelitian berlangsung. Wawancara dilakukan dengan penentuan narasumber terlebih dahulu (purposive sampling). Pemilihan narasumber oleh penulis meliputi masyarakat yang masih abai akan protokol Kesehatan (tidak menggunakan masker, seseorang yang masih berkumpul di suatu tempat pada saat penerapan PPKM atau Pemberlakuan Pembatasan Kegiatan Masyarakat. Perolehan data sekunder melalui membaca dan mengutip buku, jurnal serta website.

\section{PEMBAHASAN}

\section{Faktor Pendorong Masyarakat Abai Terhadap Regulasi Covid-19 di Indonesia}

Pemikiran masyarakat atas suatu fenomena yang terjadi merupakan suatu hal yang sah. Namun ketika suatu pemikiran dan direalisasikan kemudian timbul suatu kerugian masyarakat, hal itu merupakan suatu bentuk pelanggaran hukum. Pandemi Covid di Indonesia menimbulkan berbagai macam pemikiran oleh masyarakat. Ada yang percaya dan ada yang tidak. Masyarakat yang percaya terjadinya pandemi ini, mereka akan menerapkan protokol kesehatan dan mengurangi kegiatan di luar rumah, sesuai instruksi yang sudah digaungkan melalui beberapa peraturan yang ditetapkan oleh pemerintah.

Berbanding terbalik dengan sikap orang yang tidak percaya akan keberadaan virus ini, beberapa diantara mereka menganggap virus ini ada karena suatu konspirasi global, dikutip dari Cambridge Dictionary, dimana Teori Konspirasi adalah kepercayaan atas suatu kejadian yang pada akhirnya dipercaya sebagai suatu hal yang tidak menyenangkan atas suatu rencana rahasia dari sekelompok orang memiliki kekuasaan global. Ada dua versi pendapat di Amerika Serikat mengenai teori konspirasi Covid-19. 
Pendapat pertama adalah mereka yang ragu akan bahaya virus Covid-19 sehingga mereka mengatakan bahwa Covid-19 adalah buatan manusia yang kemudian digunakan untuk senjata biologis. Pendapat lain mengatakan bahwa Covid-19 tidak terlalu membahayakan, mereka meragukan keberadaan virus ini, bahkan aktivitas Rumah Sakit yang menangani casus covid-19 dianggap hanya rekayasa semata dengan dalih mengambil keuntungan atas meledaknya kabar virus ini. Donald Trump merupakan pencetus teori ini, walau pada akhirnya dia juga yang harus kewalahan untuk menangani melonjaknya kasus covid-19 di Amerika Serikat pada bulan Maret 2020.

Pendapat Kedua dari teori konspirasi yaitu mereka yang beranggapan bahwa virus ini didatangkan dari laboratorium China yang kemudian sengaja disebarkan oleh Rusia atau China atau beberapa tokoh dunia seperti George Soros atau Bill Gates atau bahkan WHO yang sengaja mengontrol dunia untuk menerapkan pola tatanan baru yaitu teknologi 5G dengan menanam chip kepada tiap Individu melalui suntikan vaksin (Christina, 2020: 22).

Di Indonesia, orang-orang yang mempercayai teori konspirasi tersebut akhirnya melahirkan golongan yang abai akan protokol kesehatan, mereka seenaknya saja tanpa memikirkan dampak negatif untuk orang sekitarnya. Salah satu contohnya, liputan yang dimuat oleh Kompas TV ada seorang yang menyuarakan mengenai Teori Konspirasi Virus Corona, pada saat diwawancarai program yang dibawakan oleh Aiman, dirinya menyerukan untuk melarangan mematuhi lockdown. Jika lockdown dipatuhi berarti Pemerintah tunduk dengan WHO, sementara WHO adalah kaki tangan dari Bill Gates. (sumber youtube https://www.youtube.com/watch?v=CuoMPI8qobg). Tentu saja ketika pendapat yang belum benar tersebut terdengar oleh orang yang mudah percaya tanpa mencari kebenaran info tersebut, bisa mengakibatkan penularan covid yang sangat parah.

Sementara dengan padangan lain di luar teori konspirasi, ketika penulis mewawancarai beberapa responden dari masyarakat yang abai akan protokol Kesehatan utamanya di daerah Semarang dan Kudus misalnya, 2 daerah yang dijadikan sampel penelitian ini, dengan wawacara 10 reponden pada tiap daerahnya menghasilkan anggapan bahwa mereka menganggap keberadaan kabar covid ini hanya hoax degan alasan yang tidak jelas dan hanya membuat sulit mereka untuk memenuhi kebutuhannya. Satu pendapat lain, orang tidak memakai masker dengan alasan lupa, tanggapan lain mengatakan mereka tidak merasakan adanya corona di lingkungannya karena belum ada yang terkena virus tersebut. Pendapat lain mengatakan dirinya merasa pengap dan terganggu jika menggunakan masker saat beraktivitas. Fenoma tersebut merupakan bukti adanya beberapa msyarakat yang kurang 
edukasi akan suatu bahaya yang sedang terjadi, mereka masih berpendapat bahwa ketika dirinya belum merasa sakit mereka masih dalam keadaan baik-baik saja.

Merujuk pada daerah lain, yaitu di Jakarta pada saat diterapkannya PSBB (Pembatasan Sosial Berskala Besar) atas dikeluarkannya Pergub No 88 Tahun 2020 Tentang Perubahan Atas Peraturan Gubernur Nomor 33 Tahun 2020 Tentang Pelaksanaan Pembatasan Sosial Berskala Besar dalam Penanganan Corona Virus Disease 2019 (Covid-19) Di Provinsi Daerah Khsusus Ibukota Jakarta. Melihat fenomena di wilayah Jakarta Barat, nyatanya kebanyakan warga masih meremehkan adanya aturan tersebut. Dilatarbelakangi karena masyarakat kurang kesadaran masyararakat untuk menerapkan aturan yang telah ditetapkan, masyarakat seolah tidak menganggap aturan tersebut karena kurangnya pemberian sanksi yang tegas atas aturan tersebut.

Faktor lain yang melatar belakangi sikap abai dari masyarakat adalah karena kondisi ekonomi masyarakat yang belum stabil, maka dari itu masyarakat terkesan cuek akan aturan itu. Diharapkan ada peran lebih dari Pemerintah DKI Jakarta, seperti pemberian sembako bagi warga yang kurang mampu, pemberian tunjangan Kesehatan, bahkan pengadaan Swab Test Gratis. Karena dengan terpenuhinya kebutuhan pokok masyarakat, maka akan tercipta dukungan penerapan aturan terkait covid-19 oleh masyarakat, dengan tak lupa pemerintah memberikan sanksi tegas bagi pelanggar (Michelle et al., 2020: 27).

Beberapa kejadian tersebut menggambarkan bahwa kesadaran hukum masyarakat belum berjalan dengan baik. Padahal ketika masyarakat sadar akan hukum, maka akan membentuk pola kepatuhan hukum yang optimal, sehingga tercipta sikap individu yang baik. Kesadaran hukum adalah suatu konsep abstrak yang ada pada tiap individu, kesadaran hukum berbicara mengenai keseimbangan antara kententraman dan ketertiban pada level normal.Terciptanya penataan hukum, pembentukan hukum dan efektivitas hukum sering dikaitkan dengan kesadaran hukum. Kesadaran nilai-nilai hukum yang ada pada diri manusia, yang berkaitan dengan sikap patuh terhadap hukum adalah cerminan dari kesadaran hukum.

Apabila kita berbicara mengenai kesadaran hukum, maka ada hubungannya dengan kepatuhan hukum, yang mejadi pembeda antar keduanya yaitu jika kepatuhan hukum dirasakan adanya rasa takut akan sanksi (Rosana, 2014: 23). Kepatuhan hukum diartikan sebagai suatu perilaku pembuktian atas adanya aturan hukum, dibuktikan secara sadar serta diaplikasikan dengan setia atau taat oleh individu pada setiap tindakannya (Arifuddin \& Mustari, 2018: 18).

Teori Moralitas Hukum mengatakan bahwa antara hukum dan moral jika diibaratkan bagaikan sisi mata uang yang berbeda, karena 
moral merupakan suatu modal untuk hukum dapat dijalankan sesuai dengan ketentuan. Oleh karena itu, ketika menginginkan hukum terlaksana sesuai kaidahnya, maka harus diawali dengan pembentukan pola keteraturan individu yang baik. Kesadaaran individu merupakan salah satu faktor kunci dalam proses penegakan hukum diantara beberapa faktor lain yaitu hukum, mental aparat hukum serta fasilitas pelaksanaan hukum. Hukum merupakan alat kontrol dalam masyarakat, masyarakat yang sadar akan adanya hukum yang berlaku akan melahirkan bangsa yang menghargai satu sama lain dan terciptanya keadilan sesuai cita bangsa yang tertuang di Alinea kedua Pembukaan Undang-Undang Dasar Negara Republik Indonesia Tahun 1945 (Marsinah, 2016: 88).

Menurut Hart seorang filsuf hukum Britania berpendapat bahwa dalam hukum, keadilan dan moral mempunyai keterkaitan yang sangat erat. Karena dalam pelakanaan sistem hukum tidak bisa hanya mengandalkan kekuasaan yang dijalankan oleh seorang pemimpin. Hubungan mutlak antara hukum dan moralitas yang didasarkan pada kondisi alamiah manusia (Bello, 2014: 373).

Utrecht mengatakan bahwa individu yang taat akan hukum dilatar belakangi oleh beberapa hal, diantaranya:

1. Pemahaman akan hakekat serta tujuan dari dibuatnya hokum;

2. Adanya perasaan bahwa Peraturan dibuat sebagai keberadaan hukum. Oleh sebab itu invidu tersebut merasa ikut berkepentingan atas diberlakukannya suatu aturan;

3. Merasa ingin hidup aman, nyaman dan tentram. Akhirnya seseorang menerima peraturan hukum dengan pemikiran rasionalkarena dihadirkan suatu sanksi dibalik peraturan hukum itu sendiri. Seseorang memilih untuk menaati aturan, agar tidak dihadapkan dengan kesulitan, karena mereka sadar, ketika dirinya melanggar hukum pasti otomatis akan dikenakan sanksi hukum;

4. Realitanya banyak masyarakat yang tidak menyadari sesuatu itu berdampak hukum atau tidak. Mereka baru akan sadar atas keberadaan hukum, ketika dirinya telah mendapatkan sanksi atas pelanggaran hukum yang dilakukannya serta jika kepentingannya dibatasi akan suatu aturan hokum;

5. Merasa dipaksa karena hadirnya sanksi sosial. Seseorang akan merasa malu ketika dirinya dilihat oleh khalayak umum sebagai pelanggar hukum.

Melihat realitas akan sikap abai masyarakat di tengah kondisi pandemi yang menghawatirkan. Pemerintah harus bersikap lebih tegas kepada masyarakat. Perlu dihadirkan sanksi yang bersifat lebih memaksa demi tercapainya kehidupan yang normal. Di samping itu masyarakat melalui perwakilan keluarga juga perlu dibekali pengetahuan yang lebih mengenai keberadaan dan bahayanya virus yang sedang menyerang 
negeri ini. Pemerintah dalam hal membuat kebijakan juga harus mengikuti Langkah administrative yang benar dengan terus menggandeng seluruh elemen rakyat, khususnya pemerintah daerah yang dirasa lebih dekat dengan masyarakat dan lebih tahu akan karakteristik masyarakat serta wilayahnya sendiri (Nurfurqon, 2020: 14).

\section{Fungsi Keluarga dalam Membangun Kesadaran Hukum Masyarakat}

Indonesia menjuarai kasus covid-19 di dunia dengan ditemukannya penemuan kasus baru, yang pada akhirnya berdampak beberapa negara menutup pintu bagi kedatangan orang-orang yang berangkat dari Indonesia seperti Filipina, Singapura, Uni Emirat Arab, Arab Saudi, Hong Kong, Oman, Jepang, Taiwan, negara-negara di Eropa, terutama negara dengan visa Schengen dan Bahrain.

Sejak kasus covid di Indonesia melonjak, pemerintah menerapkan Pemberlakuan Pembatasan Kegiatan masyarakat mulai 3 Juli 2021. Kegiatan masyarakat yang menimbulkan kerumunan sudah tentu ditiadakan, seperti penutupan tempat wisata, peniadaan sekolah tatap muka, bahkan minimalisasi aktivitas perkantoran. Artinya dengan adanya aturan PPKM tersebut masyarakat banyak menghabiskan kegiatannya di rumah. Dengan masyarakat di rumah saja, diharapakan keluarga mampu membangun kesadaran hukum masyarakat sesuai arahan Menteri Kesehatan untuk menghentikan penyebaran virus corona di Indonesia. Seperti peran ayah untuk terus mengingatkan kepada istri dan anakanaknya untuk tetap patuh pada protokol kesehatan, begitu juga dengan Ibu yang selalu membiasakan hal baik kepada anak-anaknya.

Keluarga adalah suatu lingkungan yang didalamnya terdapat interaksi antara orang tua dengan anak. Dengan hadirnya keluarga diharapkan anak dapat tumbuh dengan optimal karena pendidikan dan sosialisasi yang diberikan oleh orangtua sebagai figure yang baik oleh anak. Curahan perhatian dan kasih sayang yang diberikan oleh orang tua selayaknya bisa sebagai pengayom anak untuk mendapatkan pergaulan yang baik di luar keluarga (Ali \& Murdiana, 2020: 126).Di kondisi pandemi ini, diharapkan anak mendapatkan edukasi tentang kesehatan yang lebih.Karena tingkat kematian anak di Indonesia yang diakibatkan oleh covid-19 menduduki kelas tertinggi di dunia, di Indonesia kematian anak dibawah usia 18 tahun mencapai prosentasi 12,5.

Ganjar Pranowo selaku Gubernur Jawa Tengah menginstruksikan bahwa diperlukan peran keluarga untuk pencegahan covid. Beliau mengatakan bahwa mengikuti adaptasi perubahan perilaku dan budaya disiplin protokol kesehatan di era pandemi ini merupakan salah satu fungsi dari keluarga, terlebih ditengah program WFH. Para orang tua selayaknya sudah bisa mencontohkan dan memberikan edukasi tentang kesadaran hukum sejak dini kepada anak, seperti memberikan pengertian 
anak untuk tetap di rumah saja sebagai akibat dikeluarkannya Pemberlakuan Pembatasan Kegiatan Masyarakat, serta memberikan kesadaran anak untuk menjaga kebersihan, memakai maskerketika berada di luar rumah, menjaga jarak, sesuai Keputusan Menteri Kesehatan Republik Indonesia Nomor Hk.01.07/Menkes/382/2020 Tentangprotokol Kesehatan Bagi Masyarakat Di Tempat Dan Fasilitas Umum Dalam Rangka Pencegahan Dan Pengendalian Corona Virus Disease 2019 (Covid19).

Sebagaimana yang kita ketahui sederet cara dikeluarkan pemerintah untuk mengatasi wabah yang terjadi di negeri Ini, dimulai dari dikeluarkannya Undang-Undang hingga terbitnya surat edaran. Sebagai warga negara yang taat hukum, sudah selayaknya kita patuhi apabila ada solusi baik dari Pemerintah. Sesuai amanat Undang-Undang Nomor 12 Tahun 2011 Tentang Pembentukan Peraturan Perundang-Undangan, dalam Pasal 7 disebutkan Undang-Undang, Peraturan Pemerintah, Peraturan Presiden merupakan katagori Peraturan Perundang-Undangan. Dimana Perundang-Undangan. Peraturan Perundang-undangan adalah peraturan tertulis yang memuat norma hukum yang mengikat secara umum dan dibentuk atau ditetapkan oleh lembaga negara atau pejabat yang berwenang melalui prosedur yang ditetapkan dalam Peraturan Perundang-undangan.

Dalam Teori Fiksi Hukum menyatakan bahwa "setiap orang dianggap tahu akan peraturan yang telah diundangkan". Padahal kenyataannya tidak semua orang tau dan memahami peraturan perundang-undangan. Ketidak tahuan seseorang akan suatu hukum yang telah diundangkan tidak dapat membebaskan dirinya dari sanksi hokum (HSB, 2017: 251). Hal tersebut didasarkan pada suatu alesan ketika manusia hidup pasti memiliki kepentingan dari saat individu itu lahir sampai mati. Adanya kepentingan pasti juga turut hadirnya akan suatu bahya. Oleh Karena itu, individu memerlukan adanya perlindungan dari kaidah hukum. Kaidah hukum melindungi kepentingan manusia, oleh sebab itu manusia lain harus ikut menumbuhkan kesadaran hukum agar kepentingan tiap individu terlindungi.

Berangkat dari teori tersebut, keluarga memiliki peran penting, karena keluarga adalah unit terkecil dalam masyarakat yang terdiri dari suami istri, atau suami, istri dan anaknya, atau ayah dan anaknya, atau ibu dan anaknya yangmerupakan lingkungan pertama dan utama bagi perkembangan individu, karena sejak kecil anak tumbuh dan berkembang dalam lingkungan keluarga. Karena itulah peranan orang tua menjadi amat sentral dan sangat besar bagi pertumbuhan dan perkembangan anak, baik itu secara langsung maupun tidak langsung (Ariani, 2009: 12). Keberadaaan keluarga tentu memiliki fungsi, dimana fungsi keluarga 
mempunyai makna masing-masing dan mempunyai peran penting dalam keluarga dengan rincian:

1. Fungsi Keagamaan

Memberikan identitas agama serta menanamkan nilai-nilai keagamaan dan pada anak merupakan fungsi dari keluarga, sehingga menghasilkan anak yang memiliki akhlak dan bertaqwa.

2. Fungsi Sosial Budaya

Kekayaan yang dimiliki oleh bangsa Indonesia merupakan warisan untuk penerus bangsa, Oleh sebab itu melalui peran keluarga, diharapkan bisa menumbuh kembangkan kekayaan yang dimiliki oleh bangsa Indonesia agar menjadi ciri dalam berbangsa sehingga warisan nenek moyang tidak tertelan oleh zaman.

3. Fungsi Cinta Kasih

Hidup dipenuhi dengan nuansa yang penuh kasih sayang dalam keluarga merupakan dambaan setiap orang. Nuansa kasih sayang dapat diwujudkan dalam bentuk saling memberikan perhatian pada tiap anggota keluarga, oleh sebab itu keluarga memiliki peran untuk menciptakan suasana cinta dan kasih sayang dalam kehidupan berbangsa dan bernegara.

4. Fungsi Perlindungan

Keluarga merupakan tempat untuk saling melindungi, menumbuhkan kehangatan dan menciptakan rasa aman kepada tiap anggota keluarga sehingga setiap individu dalam keluarga tersebut dapat merasakan adanya tempat yang nyaman dan tentram ketika kembali ke rumah. Sehingga akan menghasilkan individu yang baik, tidak dipenuhi dengan rasa kebencian ketika berbaur di masyarakat.

5. Fungsi Reproduksi

Selain tempat untuk mengembangkan fungsi reproduksi, keluarga merupakan tempat memberikan pengenalan informasi mengenai seksualitas kepada anak-anak, di mana dalam hal ini kebanyak orang lain menganggap bahwa pendidikan seksual adalah hal yang tabu untuk dibicarakan. Nyatanya hal tersebut justru berdampak baik dalam hal memberikan pemahaman dan membekali anak agar lebih sadar dan peduli dengan kesehatan seksual masing-masing.

6. Fungsi Ekonomi

Peran orang tua dalam mendidik anak mengenai bagaimana cara mengatur keuangan memang sangat penting. Apalagi menumbuhkan sikap tidak boros terhadap anak merupakan bekal yang sangat berharga kepada anak, agar nantinya ketika anak tumbuh dewasa, mereka bisa hidup cermat dalam menggunakan uang untuk memenuhi kebutuhan hidup demi mencipatakan keluarga yang sejahtera. 
7. Fungsi Pembinaan Lingkungan

Memiliki lingkungan tempat tinggal yang selalu terjaga kebersihannya merupakan keinginan setiap individu, oleh sebab itu salah satu peran keluarga adalah memupuk kesadaran kebersihan pada tiap anggotanya agar tercipta kehidupan yang sehat dan terjamin bagi generasi yang akan datang.

8. Fungsi Sosialisasi dan Pendidikan

Keluarga sebagai tempat utama dan pertama dalam memberikan pendidikan kepada semua anak untuk bekal masa depan. Pendidikan yang diberikan oleh orang tua meliputi Pendidikan untuk mencerdaskan dan membentuk karakter anak. Fungsi sosialisasi dan Pendidikan memiliki makna juga bahwa keluarga sebagai tempat untuk mengembangkan proses interaksi dan tempat untuk belajar bersosialisasi serta berkomunikasi secara baik dan sehat. Interaksi yang sangat intensif dalam keluarga menimbulkan proses Pendidikan berjalan dengan sangat efektif. Keluarga mensosialisasi kan kepada anak tentang nilai, norma, dan cara untuk berkomunikasi dengan orang lain, mengajarkan tentang hal hal yang baik dan buruk maupun yang salah dan yang benar.

Merujuk dari beberapa fungsi di atas, tentunya Fungsi sosialisasi dan Pendidikan di dalam keluarga amatlah penting di masa pandemi covid saat ini, fungsi tersebutlah yang membuat orangtua mempunyai tanggungjawab yang lebih terhadap perkembangan anak terlebih jika melihat karakteristik anak dalam keluarga yang masih bisa terpengaruh dalam pergaulannya (Salafuddin et al., 2020: 18). Untuk itu keluargalah sebagai tempat anak dalam pemberian informasi dan pembelajaan dengan didukungpemberian batasan perilaku, memperkenalkan mana yang boleh dan yang tidak boleh akan suatu hal sebagai bekal anak untuk terjun di dunia masyarakat.

Kaitannya untuk meningkatkan kesadaran hukum masyarakat yang kemudian berdampak terjadinya kepatuhan hukum masyarakat, upaya yang paling utama yang ditempuh adalah memberikan informasi yang berkualitas di dalam keluarga, menerapkan pola interaksi dan komunikasi antar sesama anggota, ditambah dengan kepala keluarga yang turut aktif ikut program penyuluhan dan penerangan hokum oleh para pemangku kepentingan yang terkait, baik dari penegak hukum hingga kepala daerah.

Hal ini bertujuan untuk menerangkan tentang suatu aturan hukum tertentu kepada masyarakat agar mereka bisa tahu dan paham akan isi, tujuan, dan manfaat dari aturan hukum tersebut. Karena tanpa adanya penyuluhan dan penerangan, masyarakat tidak semuanya akan mengerti hakekat dari adanya aturan hukum, dan akhirnya mereka tidak memiliki 
kesadaran dan kepatuhan terhadap segala aturan yang ditetapkan oleh pemerintah (Arifuddin \& Mustari, 2018: 27).

Dalam Teori Kelekatan yang dipopulerkan oleh John Bowlby, berisi uraian relasi anak dan orang tua sejak anak masih bayi. Keterhubungan antara anak dan orangtua akan menentukan kepribadian seorang anak di masa dewasa. Tentu dalam hal ini peran orangtua sangat diperlukan untuk memberikan kekuatan emosional dan kognitif yang lebih baik bagi perkembangan anak (Cenceng, 2015: 145) Memupuk kesadaran hukum sejak dini tentu diperlukan demi terciptanya kepatuhan hukum yang optimal. Oleh sebab itu, dengan pemerintah menetapkan beberapa aturan di masa pandemi covid (covid19.go.id) utamanya kebijakan "di rumah saja" maka inilah peran keluarga yang seharusnya lebih bisa menyuarakan pentingnya penerapan protokol kesehatan demi memutus mata rantai penyebaran covid di Indonesia.

Menurut penulis bahwa apabila kebiasaan anggota keluarga khususnya orang tua untuk saling mengingatkan kebaikan, berdampak pada peningkatan kepatuhan hukum masyarakat. Orang tua yang saling mengingatkan akan anaknya akan berdampak paling besar pada kesadaran hukumnya sendiri, karena orang tua adalah panutan pribadi anak. Sehingga memaksimalkan kesadaran hukum adalah memaksimalkan peran orang tua dan keluarga. Hal tersebut sejalan dengan teori pola asuh orang tua yaitu kepribadian anak ada terpengaruh oleh cara didik yang dilakukan orang tua dengan dipengaruhi beberapa faktor, diantaranya faktor kebiasaan, budaya, kepercayaan serta kepribadian orang tua itu sendiri.

\section{SIMPULAN}

Penelitian ini dapat disimpulkan bahwa kecenderungan masyarakat abai terhadap regulasi terkait Covid-19 disebabkan oleh beberapa faktor salah satunya adalah teori konspirasi, di mana sebagian masyarakat beranggaan bahwa virus tersebut hanyalah rekayasa yang sengaja didesain untuk mengacaukan perekonomian dunia. Kebijakan pemerintah saat ini dengan menerapkan protokol kesehatan dalam segala aktivitas seperti memakai masker justru masih terdapat masyarakat yang beranggapan bahwa kebijakan tersebut tidak populis dan memakai masker hanyalah akan mengganggu aktivitas mereka karena merasa pengap. Kondisi demikian itu tentu sangat memprihatinkan apalagi sebagian mayarakat tidak percaya dengan keberadaan Covid-19, sedangkan penyakit tersebut memang benar-benar ada.

Keluarga memiliki andil yang signifikan dalam membentuk sikap dan perilaku anggotanya sehingga memiliki kesadaran hukum, yaitu melalui optimalisai fungsi sosialisasi dan edukasi (pendidikan) oleh orang tua. Kebiasaan anggota keluarga khususnya orang tua untuk saling 
mengingatkan menjaga kesehatan dan mengikuti anjuran pemerintah tentang pencegahan penyebaran Covid-19, secara implisit dapat berimplikasi terhadap peningkatan kepatuhan hukum masyarakat. Dengan kata lain, orang tua yang saling mengingatkan anaknya untuk peduli terhadap menjaga kesehatan dan mematuhi aturan hukum akan berdampak paling besar pada kesadaran hukumnya sendiri, karena orang tua adalah panutan pribadi anak. Sehingga memaksimalkan kesadaran hukum adalah memaksimalkan peran orang tua dan keluarga.

\section{DAFTAR PUSTAKA}

\section{Buku-buku}

Ariani, T. A. (2009). Korelasi Pola Hubungan Orangtua-Anak dan Keberfungsian Keluarga dengan Perkembangan Anak Usia Prasekolah.

Marsinah, R. (2016). Kesadaran Hukum Sebagai Alat Pengendali. 6(2), 86-96.

Michelle, E., Betarli Lengkong, K., \& Jusuf, M. (2020). Ketaatan Dan Kepatuhan Hukum Masyarakat Terhadap Peraturan Psbb Masa Transisi Bedasarkan Pergub No. 88 Tahun 2020 Di Wilayah Jakarta

\section{Jurnal-jurnal}

Ali, Z. Z., \& Murdiana, E. (2020). Peran Dan Fungsi Keluarga Dalam Pendampingan Pendidikan Anak Ditengah Pandemi Covid-19. JSGA: Jurnal Studi Gender Dan Anak, 2(01), 120-137.

Ashidiqie, M. L. I. I. (2020). Peran Keluarga Dalam Mencegah Coronavirus Disease 2019. SALAM: Jurnal Sosial Dan Budaya Syar-I, 7(8), 911-922. https://doi.org/10.15408/sjsbs.v7i8.15411

Bello, P. C. (2014). Hubungan Hukum Dan Moralitas Menurut H.L.a Hart. Jurnal Hukum E Pembangunan, 44(3), 373. https://doi.org/10.21143/jhp.vol44.no3.27

Cenceng. (2015). Perilaku Kelekatan Pada Anak Usia Dini (Perspektif John Bowlby). Lentera, IXX(2), 141-153.

Christina, E. (2020). Pandemi Covid-19 adalah 666? Endah Christina. Jurnal Teologi Pentasoka, 1, 1-23.

Hasibuan, Z. (2014). Kesadaran Hukum Dan Ketaatan Hukum Masyarakat Dewasa Ini. Publik, 2(2), 78-92.

HSB, A. M. (2017). Mengkritisi Pemberlakuan Teori Fiksi Hukum (Criticising Enactment Of Law Fiction Theory). Jurnal Penelitian Hukum De Jure, 16(3), 251. https:/ / doi.org/10.30641/dejure.2016.v16.251-264 
Indriya. (2020). Kosep Tafakur Dalam Al-Quran Dalam Menyikapi Corona Cirus. Jurnal Sosial Budaya, 7(3), 211-216.

Michelle, E., Betarli Lengkong, K., \& Jusuf, M. (2020). Ketaatan Dan Kepatuhan Hukum Masyarakat Terhadap Peraturan Psbb Masa Transisi Bedasarkan Pergub No. 88 Tahun 2020 Di Wilayah Jakarta Barat. ADIL: Jurnal Hukum, 11(2).

No, V., \& Mona, N. (2020). Konsep Isolasi Dalam Jaringan Sosial Untuk Meminimalisasi Efek Contagious (Kasus Penyebaran Virus Corona Di Indonesia). Jurnal Sosial Humaniora Terapan, 2(2), 117-125. https:/ / doi.org/10.7454/jsht.v2i2.86

Nurfurqon, A. (2020). Analisis Kebijakan Pemerintah Daerah Dalam Penanganan Covid-19: Perspektif Hukum Administrasi Negara. Jurnal Yustika: Media Hukum Dan Keadilan, 23(01), 13-23. https:/ / doi.org/10.24123/yustika.v23i01.2864

Putri, N. F., Vionia, E., \& Michael, T. (2020). Pentingnya Kesadaran Hukum Dan Peran Masyarakat Indonesia Dalam Menghadapi Penyebaran Berita Hoax Covid-19. Media Keadilan: Jurnal Ilmu Hukum, 11(1), 98. https:// doi.org/10.31764/jmk.v11i1.2262

Rahadi, D. R. (2017). Perilaku Pengguna Dan Informasi Hoax Di Media Sosial. Jurnal Manajemen Dan Kewirausahaan, 5(1), 58-70. https:/ / doi.org/10.26905/jmdk.v5i1.1342

Rochanah, R. (2020). Peran Mahasiswa Pgmi Iain Kudus Sebagai Agent of Change Di Masa Pandemi Covid-19. ELEMENTARY: Islamic Teacher Journal, 8(2), 339. https:// doi.org/10.21043/elementary.v8i2.8094

Rosana, E. (2014). Kepatuhan Hukum Sebagai Wujud Kesadaran Hukum Masyarakat. Jurnal TAPIs, 10(1), 1-25.

Salafuddin, S., Santosa, S., Utomo, S., \& Utaminingsih, S. (2020). Pola Asuh Orang Tua dalam Penguatan Pendidikan Karakter Anak (Studi Kasus pada Anak TKW di SDN Pidodo Kecamatan Karangtengah). JPAI: Jurnal Perempuan Dan Anak Indonesia, 2(1), 18. https:/ / doi.org/10.35801/jpai.2.1.2020.28276

Tundjung HS, T. H., Kurnia, I., \& Adhari, A. (2020). Peningkatan Kesadaran Hukum Masyarakat Terhadap Peran Masyarakat Dalam Pencegahan Dan Penanggulangan Kekerasan Dalam Rumah Tangga. Jurnal Bakti Masyarakat Indonesia, 2(2), 309-314.

Yuliati, Y. (2021). Peran Keluarga Dalam Pencegahan Wabah Covid-19. Jurnal Pengabdian Masyarakat AbdiMas, 7(2). https://doi.org/10.47007/abd.v7i2.3968 